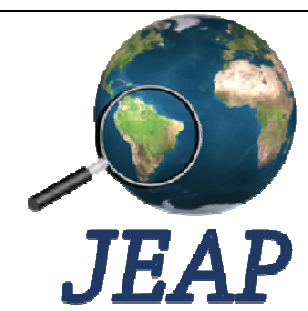

ISSN: 2525-815X

\section{Journal of Environmental} Analysis and Progress

Journal homepage: www.jeap.ufrpe.br/

\title{
Estabelecimento de Myracrodruon urundeuva Allemão com inoculação de micro- organismo sob diferentes condições de luminosidades
}

\section{Establishment of Myracrodruon urundeuva Allemão with microorganism inoculation under different conditions of lightness}

Maria Jucicléa dos Santos Medeiros ${ }^{\mathrm{a}}$, Rafaela Lopes de Sousa ${ }^{\mathrm{a}}$, Douglas Moreira de Oliveira ${ }^{\mathrm{a}}$, Ana Paula Alves da Silva ${ }^{\mathrm{a}}$, André Luiz Alves de Lima ${ }^{\mathrm{a}}$

${ }^{a}$ Universidade Federal Rural de Pernambuco-UFRPE, Unidade Acadêmica de Serra Talhada-UAST. Avenida Gregório Ferraz Nogueira, s/n, José Tomé de Souza Ramos, Serra Talhada, Pernambuco, Brasil. Caixa Postal: 063. CEP: 56.909-535. E-mail: mary-cleia1@ hotmail.com.

\section{A R T I C L E I N F O}

Recebido 30 Jun 2017

Aceito 04 Ago 2017

Publicado 22 Set 2017

\begin{abstract}
A B S T R A C T
$\overline{\text { In semi-arid environments, the plants are subject to stressful conditions due to high }}$ temperatures, light intensity and long drought, which are limiting for the establishment of seedlings. One way of minimizing stress is by inoculating rhizobacteria which promote plant growth (RPGP). The objective of this study was to evaluate the effectiveness of RPCP inoculation in the development of Myracrodruon urundeuva Allemão seedlings in different light conditions. Four treatments were applied: full sun with inoculum; full sun without inoculum; $70 \%$ shade with inoculum and $70 \%$ shade without inoculum. Data were collected biweekly for height, diameter, the number of leaves and leaf temperature (Tf). The vapor pressure deficit was determined by the temperature and humidity of the air. Parameters of leaf water potential, biomass, leaf area, specific leaf area and root area were evaluated. The seedlings presented higher growth under shading, demonstrating a mechanism to develop better in low light, and inoculation of the bacterium provided an increase in height and diameter of the seedlings, besides higher Tf on most days. The seedlings of the treatments in the sun invested more in radicular biomass, whereas in the shading they invested more in the aerial part. The water potential did not vary among the treatments, indicating that they adjusted to the submitted conditions. The use of RPGP is very promising, especially for the implantation of plant species in the recovery of degraded areas, as well as the condition of greater shading favors the initial stage of development of the seedlings. Keywords: Aroeira, caatinga, seedling, rhizobacteria, functional traits.
\end{abstract}

\section{R E S U M O}

Em ambientes semiáridos as plantas estão sujeitas a condições estressantes devido altas temperaturas, intensidade luminosa e longa estiagem, que são limitantes para estabelecimento das plântulas. Uma forma de minimizar os estresses é inoculando rizobactérias promotoras do crescimento de plantas (RPCP). Objetivou-se avaliar, em diferentes condições de luminosidade, a eficácia da inoculação de uma RPCP no desenvolvimento de plântulas de Myracrodruon urundeuva Allemão. Foram aplicados 4 tratamentos: pleno sol com inóculo; pleno sol sem inóculo; $70 \%$ sombreamento com inóculo e $70 \%$ sombreamento sem inóculo. Realizou-se coletas de dados quinzenalmente de altura, diâmetro, número de folhas e temperatura foliar (Tf). O déficit de pressão de vapor foi determinado através da temperatura e umidade do ar. Foram avaliados: potencial hídrico foliar, biomassa, área foliar, área foliar específica e área radicular. As plântulas apresentaram maior crescimento sob 
sombreamento, demonstrando mecanismo de desenvolver-se melhor em baixa luminosidade, e a inoculação da bactéria proporcionou aumento em altura e diâmetro das plântulas, além de maior Tf na maioria dos dias. As plântulas dos tratamentos ao sol investiram mais em biomassa radicular, enquanto que no sombreamento investiram mais na parte aérea. O potencial hídrico não variou entre os tratamentos, indicando que se ajustaram às condições submetidas. O uso RPCP é bastante promissor, especialmente, para implantação de espécies vegetais na recuperação de áreas degradadas, bem como a condição de maior sombreamento favorece o estádio inicial de desenvolvimento das plântulas.

Palavras-Chave: Aroeira, caatinga, plântula, rizobactéria, traços funcionais.

\section{Introdução}

As Florestas Tropicais Sazonalmente Secas (FTSS) são regiões que recebem menos de $100 \mathrm{~mm}$ de chuva em um período mínimo de 5 a 6 meses (Gentry, 1995). No Brasil, a caatinga é a maior representação das FTSS (Miles et al., 2006), e é um domínio que ocupa a maior parte da região Nordeste do país com clima semiárido (Sampaio \& Rodal, 2000). O domínio Caatinga é caracterizado por elevadas temperaturas, alta incidência de radiação solar e alta demanda evaporativa, que acarretam em deficiência hídrica para as plantas (Andrade Lima, 1989) e, consequentemente, limitando seu desenvolvimento (Kozlowski et al., 1991), especialmente, quando trata-se de plântulas, que são mais frágeis e susceptíveis às condições estressantes do ambiente. Essas condições se tornam mais graves quando se observa que muitos ambientes naturais foram severamente alterados por ações antrópicas (Leal et al., 2005). Apesar disso, poucos são os trabalhos que usam alguma alternativa tecnológica para minimizar os efeitos dos estresses ambientais, tal como o uso de rizobactérias promotoras do crescimento de plantas (RPCP) (Yang et al., 2009). Aliado a isso, o efeito do sombreamento no desenvolvimento de plantas de florestas tropicais também tem sido documentado (Augspurger, 1984; Engel \& Pogiani, 1990; Fetene \& Feleke, 2001), embora ainda pouco explorado em florestas tropicais secas.

Plantas sujeitas a condições estressantes, como no semiárido, podem ter um melhor desenvolvimento se forem submetidas a inoculação de bactérias benéficas (Santos et al., 2014). Por meio de muitos mecanismos, as RPCP são capazes de promover o desenvolvimento dos vegetais (Silveira, 2008; Moreira \& Siqueira, 2006). As bactérias do gênero Azospirillum, por exemplo, são capazes de sintetizar fitormônios do crescimento vegetal e auxiliam na fixação de nitrogênio (Fallik \& Okon, 1996). Entre as espécies vegetais da Caatinga, Myracrodruon urundeuva Allemão, conhecida como aroeira, se destaca por sua importância medicinal e madeireira (Andrade et al., 2000). Por ser utilizada para diversos fins, a aroeira está entre as espécies arbóreas mais exploradas (Rizzini, 1995) e está na categoria vulnerável da lista oficial de espécies da flora brasileira ameaçadas de extinção (IBAMA, 2008). Diante desta situação, esta espécie torna-se bastante interessante para avaliar o efeito da inoculação de RPCP e de diferentes níveis de sombreamento no desenvolvimento de suas plântulas.

\section{Material e Métodos}

O experimento foi realizado no município de Serra Talhada, Pernambuco, na Unidade Acadêmica de Serra Talhada (UAST) da Universidade Federal Rural de Pernambuco (UFRPE), localizada nas seguintes coordenadas geográficas 753'21' e 757'36" S e 38¹8'42” e 38 $17^{\prime} 7^{\prime \prime}$ W. A temperatura média anual é em entorno de $23,8^{\circ} \mathrm{C}$. De acordo com a classificação de Köppen, o clima é do tipo BSwh' (Sacramento, et al., 2013), semiárido, com precipitação média anual de 653,2 $\mathrm{mm}$, período chuvoso de dezembro a maio (Silva \& Almeida, 2013) e umidade relativa do ar de $63 \%$ (Barbosa et al., 2013). As sementes de Myracrodruon urundeuva Allemão foram coletadas na Fazenda Barro, em Serra Talhada, PE, e armazenadas em recipiente fechado sob refrigeração. $\mathrm{O}$ beneficiamento das sementes ocorreu a partir da eliminação de impurezas, como restos de frutos, para serem esterilizadas superficialmente utilizando-se álcool a $70 \%$ por 30 segundos e hipoclorito de sódio $1,3 \%$ por quatro minutos e, em seguida, lavadas em água destilada.

Os tratamentos foram estabelecidos em função da luminosidade, a pleno sol e a $70 \%$ de sombreamento, com inoculação de Rizobactérias Promotoras do Crescimento de Plantas (RPCP) e controle sem inoculação. Estas RPCP foram obtidas a partir da cepa de Azospirillum lipoferum (BR-11080), isolada e caracterizada pela EMBRAPA Agrobiologia, Seropédica_RJ e inoculada e crescida em meio caldo nutriente ( $5 \mathrm{~g}$ de cloreto de sódio e 1,5 g de extrato de carne), por 48 horas, a temperatura ambiente, sob agitação. Em seguida, o meio contendo as células bacterianas foi centrifugado à $10.000 \mathrm{~g}$ por 5 minutos, e o sobrenadante foi descartado. Foi adicionado então $20 \mathrm{~mL}$ de água destilada 
esterilizada para homogeneizar as células depositadas no fundo do tubo. Em seguida, procedeu-se a leitura de densidade ótica (DO) das soluções no espectrofotômetro (biochrom), ajustando-as pela adição de água destilada esterilizada até que se atingisse DO próxima de 1,0 a $535 \mathrm{~nm}$, indicando a presença de $10^{8}$ Unidades Formadoras de Colônia. $\mathrm{mL}^{-1}$ de solução (Kuss et al., 2007). A inoculação foi realizada pela adição de $5 \mathrm{ml}$ da suspensão bacteriana, quantificada, onde sementes ficaram imersas por duas horas.

Posteriormente, as sementes foram separadas em dois lotes, cada um com 200 sementes, sendo um para a inoculação e outro para o tratamento controle. Após a inoculação, as sementes foram postas para germinar em solo, considerando ambas as situações, com e sem inóculo. Em cada saco com solo foram colocadas doze sementes para aumentar a chance de sucesso na obtenção de plântulas, sendo que após a germinação, foram cortadas as plântulas dos sacos que possuíam mais de uma, ou seja, foi deixado apenas uma plântula por saco, as quais foram irrigadas com $100 \%$ da evapotranspiração de referência (ET0). As sementes foram colocadas para germinar submetidas aos tratamentos, descritos a seguir. Cada tratamento foi composto por 10 repetições (plântulas). Os tratamentos foram os seguintes: 1) pleno sol, sementes com inóculo das RPCP; 2) pleno sol, sem inóculo; 3) $70 \%$ de sombreamento, sementes com inóculo das RPCP; 4) $70 \%$ de sombreamento, sementes sem inóculo das RPCP. Os tratamentos de $70 \%$ de sombreamento foram conduzidos em uma estrutura de telado feito com madeira e sombrite. Todos os tratamentos ficaram sobre uma bancada montada com madeira. Um mês após a germinação das sementes iniciou-se a realização das medidas biométricas. Durante o período experimental foram medidos o diâmetro do coleto, utilizando um paquímetro digital (LeeTools), a altura da plântula, com uma fita métrica, o número de folhas e cinco medidas de temperatura foliar ao longo do dia, utilizando um termômetro com infravermelho (ScanTemp - 600.00). Esta última variável foi medida quinzenalmente. $\mathrm{Na}$ ocasião da medida da temperatura foliar também foram realizadas medidas da temperatura e umidade do ar, utilizando-se um termohigrômetro (Incoterm), para relacionar com a temperatura foliar.

Após três meses de tratamento, as plântulas foram avaliadas quanto aos parâmetros morfofisiológicos. Neste caso, o potencial hídrico foliar foi avaliado ao amanhecer, em três indivíduos por tratamento, utilizando-se uma bomba de pressão tipo Scholander (100 bares).
Em seguida, as folhas foram retiradas e imediatamente pesadas em balança digital com quatro casas decimais. Após isso, foram digitalizadas em scanner de mesa para determinar a área foliar usando o programa Lafore (www.landeco.uni-oldenburg.de/21342.html). Em seguida, foram secas em estufa com temperatura de $60^{\circ} \mathrm{C}$ por três dias, para obter o peso da massa seca e realizar as medidas de área foliar específica (AFE), como a relação da área foliar por sua massa seca (Pérez-Harguindeguy et al., 2013).

Após a retirada das folhas, os caules foram separados das raízes e conduzidos para a estufa de circulação forçada de ar a $60^{\circ} \mathrm{C}$, por três dias, conforme o protocolo proposto por Cornelissen et al. (2003). As raízes foram cuidadosamente retiradas dos sacos, usando-se água corrente e, em seguida, foram obtidas as medidas de comprimento e diâmetro, utilizando-se um paquímetro digital, para calcular a área superficial do sistema radicular. Posteriormente foram secas à $60^{\circ} \mathrm{C}$ em estufa de circulação forçada de ar, por três dias, para serem triadas as raízes finas ( $\leq 2 \mathrm{~mm}$ de diâmetro) e raízes grossas ( $\geq 2 \mathrm{~mm}$ de diâmetro). Os dados meteorológicos foram obtidos da estação meteorológica automática, tipo PCD, do Instituto Nacional de Meteorologia (INMET), instalada a cerca de 100 metros da área experimental.

Os dados foram submetidos a análise descritiva, calculando-se a média aritmética e o desvio padrão com ajuda do Excel. Utilizando-se o programa ASSISTAT Versão 7.7 beta (pt) foi realizada a análise de variância dos dados e as médias foram comparadas pelo teste de Tukey a $5 \%$ de probabilidade.

\section{Resultados}

$\begin{array}{ccc}\text { A inoculação das RPCP e o } & \text { e } \\ \text { sombreamento proporcionaram } & \text { melhor }\end{array}$ desenvolvimento das plântulas, como pode-se verificar, houve diferença significativa na altura e diâmetro das plântulas entre os tratamentos para cada período avaliado, exceto no último dia de análise (Tabela 1). Nota-se que as plântulas apresentaram maior altura e diâmetro nos tratamentos sob sombreamento, independente da presença ou não das RPCP (Tabela 1). Apesar disso, as plântulas do tratamento $70 \%$ de sombra com inóculo obtiveram maiores valores absolutos em todos os dias analisados, desta forma, sugerindo uma tendência do efeito positivo das RPCP no desenvolvimento das plântulas. Também foi possível verificar que as plântulas a pleno sol com inóculo tiveram melhores resultados em relação as plântulas do tratamento a pleno sol sem inóculo, exceto no primeiro dia de análise (Tabela 
1), contudo não diferiram significativamente.

mais influenciou no crescimento das plântulas.

Portanto, o ambiente sombreado foi o fator que

Tabela 1. Biometria de plântulas de Myracrodruon urundeuva Allemão cultivadas sob diferentes condições de luminosidade e presença/ausência de inóculo. ALT = altura da plântula; $\mathrm{DC}=$ diâmetro do coleto; $\mathrm{NF}=$ número de folhas.

\begin{tabular}{|c|c|c|c|c|}
\hline Avaliações quinzenais & Tratamento & ALT (cm) & DC (mm) & NF \\
\hline \multirow{4}{*}{ 08/12/2016 } & Pleno sol com inóculo & $7,74 \underline{ \pm 2}, 61 \mathrm{bc}$ & $0,94 \pm 0,33 \mathrm{ab}$ & $3,7 \pm 0,7 \mathrm{bc}$ \\
\hline & Pleno sol sem inóculo & $5,40 \pm 1,40 \mathrm{c}$ & $0,60 \pm 0,26 \mathrm{a}$ & $3,3 \pm 0,5 \mathrm{c}$ \\
\hline & $70 \%$ sombra com inóculo & $11,25 \pm 2,49 \mathrm{a}$ & $1,21 \pm 0,43$ a & $5,0 \pm 0,5 \mathrm{a}$ \\
\hline & $70 \%$ sombra sem inóculo & $10,61 \pm 3,24 \mathrm{ab}$ & $1,17 \pm 0,33 \mathrm{a}$ & $4,3 \pm 0,7 \mathrm{ab}$ \\
\hline \multirow{4}{*}{$22 / 12 / 2016$} & Pleno sol com inóculo & $4,93 \pm 1,08 \mathrm{~b}$ & $0,60 \pm 0,17 \mathrm{~b}$ & $4,9 \pm 1,8 \mathrm{ab}$ \\
\hline & Pleno sol sem inóculo & $4,23 \pm 1,04 \mathrm{~b}$ & $0,72 \pm 0,11 \mathrm{ab}$ & $4,0 \pm 0,8 \mathrm{~b}$ \\
\hline & $70 \%$ sombra com inóculo & $7,99 \pm 0,95$ a & $0,81 \pm 0,13 \mathrm{a}$ & $6,1 \pm 1,2 \mathrm{a}$ \\
\hline & $70 \%$ sombra sem inóculo & $6,82 \pm 1,13$ a & $0,75 \pm 0,14 \mathrm{ab}$ & $6,1 \pm 0,9$ a \\
\hline \multirow{4}{*}{ 05/01/2017 } & Pleno sol com inóculo & $9,80 \pm 3,83 \mathrm{~b}$ & $1,30 \pm 0,45 \mathrm{bc}$ & $6,9 \pm 2,0 \mathrm{bc}$ \\
\hline & Pleno sol sem inóculo & $7,21 \pm 3,18 b$ & $0,94 \pm 0,27 \mathrm{c}$ & $5,4 \pm 2,4 \mathrm{c}$ \\
\hline & $70 \%$ sombra com inóculo & $17,77 \pm 3,13 \mathrm{a}$ & $1,81 \pm 0,24$ a & $9,6 \pm 1,3 \mathrm{a}$ \\
\hline & $70 \%$ sombra sem inóculo & $15,25 \pm 3,08 \mathrm{a}$ & $1,57 \pm 0,24 \mathrm{ab}$ & $8,7 \pm 1,3 \mathrm{ab}$ \\
\hline \multirow{4}{*}{ 19/01/2017 } & Pleno sol com inóculo & $10,30 \pm 4,58 \mathrm{~b}$ & $1,75 \pm 0,68 \mathrm{a}$ & $8,3 \pm 2,5 \mathrm{ab}$ \\
\hline & Pleno sol sem inóculo & $8,78 \pm 4,60 \mathrm{~b}$ & $1,52 \pm 0,70$ a & $6,9 \pm 3,2 b$ \\
\hline & $70 \%$ sombra com inóculo & $20,27 \pm 2,79 a$ & $2,21 \pm 0,24 \mathrm{a}$ & $10,3 \pm 1,8 \mathrm{a}$ \\
\hline & $70 \%$ sombra sem inóculo & $18,50 \pm 4,06 \mathrm{a}$ & $1,97 \pm 0,51 \mathrm{a}$ & $10,3 \pm 1,7 \mathrm{a}$ \\
\hline
\end{tabular}

Médias \pm desvio padrão, seguidos da mesma letra, não diferem significativamente entre si pelo teste de Tukey a $5 \%$ de probabilidade.

É importante ressaltar que o estresse causado pela alta irradiância solar ocasionou a morte de algumas plântulas que estavam a sol, das quais quatro eram do tratamento sem inóculo e apenas uma do tratamento com inóculo, desta forma, evidenciando que o inóculo minimizou o estresse.

Quanto a taxa de emissão de folhas, durante todos os dias de avaliações, as plântulas que cresceram no ambiente a $70 \%$ sombreado apresentaram, significativamente, um maior número de folhas do que nos tratamentos a pleno sol (Tabela 1). Embora não exista diferença significativa entre os tratamentos à sombra, nos dias 08/12/2016 e 05/01/2017, as plântulas do sombreamento com inóculo produziram mais folhas (média de 5,0 e 9,6 folhas nas respectivas datas) em relação às sem inóculo (média de 4,3 e 8,7 folhas nas respectivas datas). Da mesma forma, as plântulas a pleno sol com inóculo emitiram mais folhas em todos os dias analisados quando comparado ao tratamento sem inóculo, contudo não houve diferença significativa entre esses dois tratamentos (Tabela 1).

\section{Temperatura foliar}

No primeiro dia de análise $(08 / 12 / 2016)$, as plântulas do tratamento pleno sol com inóculo apresentaram as maiores temperaturas foliares (Tf) ao longo do dia em relação aos outros tratamentos, diferindo significativamente do tratamento pleno sol sem inóculo às $8 \mathrm{~h} \mathrm{e} 12 \mathrm{~h}$ (Tabela 2). Apenas às $15 \mathrm{~h}$ (horário mais quente do dia), as plântulas do tratamento pleno sol sem inóculo apresentaram maior $\mathrm{Tf}$, apesar de não haver diferença significativa (Tabela 2).

No segundo dia de medida (22/12/2016) houve uma maior variação de temperatura foliar entre os tratamentos ao longo do dia, embora tenha ocorrido diferença significativa apenas no final do dia (Tabela 2). Observa-se, também, que nas primeiras horas e no final deste dia, a $\mathrm{Tf}$ foi maior nos tratamentos com inóculo, tanto no sol quanto na sombra em relação àquelas sem inóculo, e nos horários mais quentes, entre 12 e 15 $\mathrm{h}$, as plântulas dos tratamentos sem inóculo apresentam as maiores Tf. Nas datas seguintes verificou-se maior $\mathrm{Tf}$ das plântulas do tratamento sob pleno sol, com inóculo, ao longo do dia, entretanto, apenas no último dia houve uma 
Tabela 2. Avaliações quinzenais de temperatura foliar $\left({ }^{\circ} \mathrm{C}\right)$, ao longo do dia das plântulas de Myracrodruon urundeuva Allemão.

\begin{tabular}{|c|c|c|c|c|c|c|}
\hline \multirow{2}{*}{ Avaliações (datas) } & \multirow{2}{*}{ Tratamento } & \multicolumn{5}{|c|}{ Temperatura foliar $\left({ }^{\circ} \mathrm{C}\right)$ (Hora do dia) } \\
\hline & & 8:00 & 10:00 & 12:00 & 15:00 & 17:00 \\
\hline \multirow{4}{*}{ 08/12/2016 } & Pleno sol com inóculo & $33,26 \mathrm{aA}$ & $37,02 \mathrm{aA}$ & $42,44 \mathrm{aA}$ & $35,71 \mathrm{aA}$ & $34,53 \mathrm{aA}$ \\
\hline & Pleno sol sem inóculo & $28,79 \mathrm{aB}$ & $35,59 \mathrm{aA}$ & $32,74 \mathrm{aB}$ & $36,46 \mathrm{aA}$ & $34,31 \mathrm{aA}$ \\
\hline & $70 \%$ Sombra com inóculo & $27,85 \mathrm{bA}$ & $33,13 \mathrm{aA}$ & $29,14 \mathrm{bA}$ & $35,67 \mathrm{aA}$ & $33,42 \mathrm{aA}$ \\
\hline & 70\% Sombra sem inóculo & $29,32 \mathrm{aA}$ & $34,54 \mathrm{aA}$ & $33,21 \mathrm{aA}$ & $35,62 \mathrm{aA}$ & $33,63 \mathrm{aA}$ \\
\hline \multirow{4}{*}{ 22/12/2016 } & Pleno sol com inóculo & $26,81 \mathrm{aA}$ & $27,84 \mathrm{aA}$ & $29,73 \mathrm{aA}$ & $30,02 \mathrm{aA}$ & $29,17 \mathrm{bA}$ \\
\hline & Pleno sol sem inóculo & $24,75 \mathrm{aA}$ & $26,86 \mathrm{aA}$ & $32,49 \mathrm{aA}$ & $33,59 \mathrm{aA}$ & $28,86 \mathrm{aA}$ \\
\hline & $70 \%$ Sombra com inóculo & $25,50 \mathrm{aA}$ & $30,34 \mathrm{aA}$ & $26,24 \mathrm{aA}$ & $33,42 \mathrm{aA}$ & $30,95 \mathrm{aA}$ \\
\hline & 70\% Sombra sem inóculo & $25,10 \mathrm{aA}$ & $28,40 \mathrm{aA}$ & $30,40 \mathrm{aA}$ & $34,84 \mathrm{aA}$ & $28,45 \mathrm{aB}$ \\
\hline \multirow{4}{*}{ 05/01/2017 } & Pleno sol com inóculo & $26,20 \mathrm{aA}$ & $32,95 \mathrm{aA}$ & $34,23 \mathrm{aA}$ & $32,07 \mathrm{aA}$ & $28,43 \mathrm{aA}$ \\
\hline & Pleno sol sem inóculo & $26,18 \mathrm{aA}$ & $29,60 \mathrm{aB}$ & $30,11 \mathrm{aB}$ & $30,18 \mathrm{aB}$ & $27,44 \mathrm{aA}$ \\
\hline & 70\% Sombra com inóculo & $26,52 \mathrm{aA}$ & $27,49 \mathrm{bA}$ & $24,06 \mathrm{bA}$ & $28,08 \mathrm{bA}$ & $28,04 \mathrm{aA}$ \\
\hline & 70\% Sombra sem inóculo & $25,91 \mathrm{aA}$ & $29,33 \mathrm{aA}$ & $26,10 \mathrm{bA}$ & $28,83 \mathrm{aA}$ & $27,94 \mathrm{aA}$ \\
\hline \multirow{4}{*}{ 19/01/2017 } & Pleno sol com inóculo & 27,83 aA & 38,60 aA & 43,32 aA & 39,43 aA & $31,06 \mathrm{aA}$ \\
\hline & Pleno sol sem inóculo & $25,42 \mathrm{aA}$ & $29,96 \mathrm{aB}$ & $38,00 \mathrm{aA}$ & $41,49 \mathrm{aA}$ & $31,29 \mathrm{aA}$ \\
\hline & 70\% Sombra com inóculo & $25,64 \mathrm{aA}$ & $26,12 \mathrm{bA}$ & $27,84 \mathrm{aA}$ & $30,30 \mathrm{aA}$ & $31,11 \mathrm{aA}$ \\
\hline & 70\% Sombra sem inóculo & $25,23 \mathrm{aA}$ & $27,02 \mathrm{aA}$ & $24,18 \mathrm{aA}$ & $28,88 \mathrm{aA}$ & $31,03 \mathrm{aA}$ \\
\hline
\end{tabular}

Letras maiúsculas comparam tratamentos com inóculo e sem inóculo dentro de cada tratamento de luz, em cada hora do dia, e letras minúsculas comparam tratamentos pleno sol e $70 \%$ sombreamento independente da inoculação, dentro de cada hora do dia, ao nível de 5\% de probabilidade.

Déficit de pressão de vapor

Em todos os dias analisados observa-se que o déficit de pressão de vapor (DPV) teve o maior pico às $15 \mathrm{~h}$, aproximadamente $5,0 \mathrm{KPa}$ no primeiro dia, 4,5 $\mathrm{KPa}$ no segundo, 4,0 KPa no terceiro e 3,5 KPa no último dia, seguido de uma redução a partir desse horário, quando, às $17 \mathrm{~h}$, ocorreu um decaimento em todos os dias (Figura $1)$.

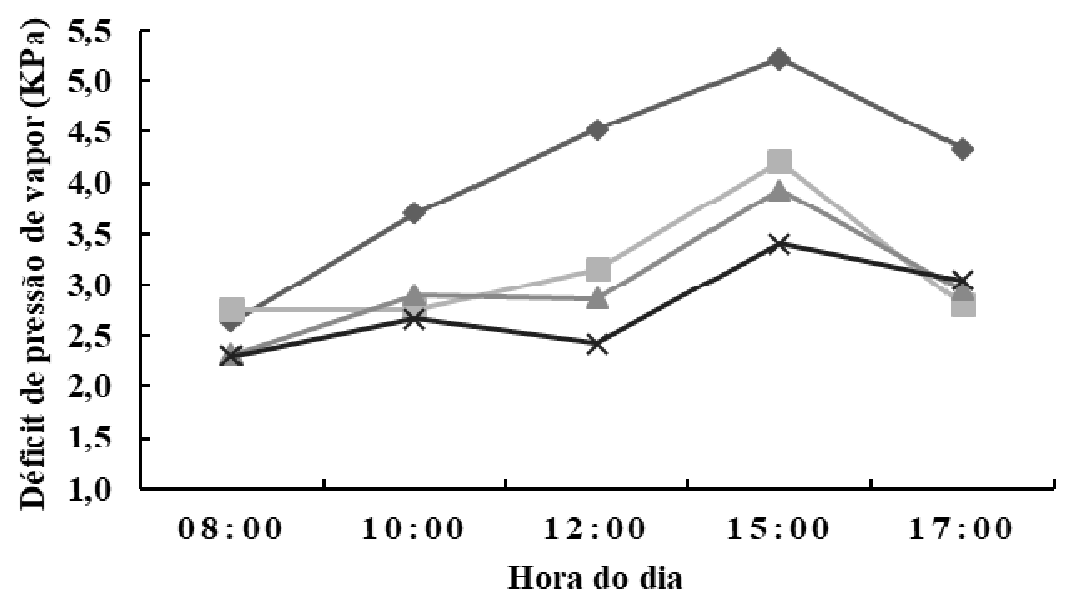

$\multimap-08 / 12 / 2016-22 / 12 / 2016 \multimap-05 / 01 / 2017 \rightarrow-19 / 01 / 2017$

Figura 1. Avaliações quinzenais de déficit de pressão de vapor (KPa), ao longo do dia das plântulas de Myracrodruon urundeuva Allemão. 


\section{Biomassa}

Dentre os órgãos analisados nas plântulas, apenas nas raízes finas foi registrada diferença significativa, com o tratamento a $70 \%$ de sombreamento sem inóculo mostrando valores quase três vezes maior que o obtido no tratamento a pleno sol com inóculo (Tabela 3). Nota-se que as plântulas deste tratamento apresentaram um baixo valor de biomassa de raízes finas, porém com maior investimento na produção de raízes tuberosas $(1,339 \mathrm{~g})$ e folhas $(0,868 \mathrm{~g})$. Ao relacionar a biomassa radicular com a aérea, observa-se que, apesar de não haver diferença significativa, as plântulas a pleno sol investiram mais na produção de biomassa de raízes em detrimento daquela relativa à produção de parte aérea, ao contrário daquelas que estavam sob $70 \%$ de sombreamento, as quais investiram mais na produção de biomassa da parte aérea (Tabela 3).

Tabela 3. Biomassa dos diferentes órgãos das plântulas de Myracrodruon urundeuva Allemão. LF = Lâmina foliar; $\mathrm{C}=$ caule; $\mathrm{R}=$ raque; $\mathrm{RF}=$ raízes finas; $\mathrm{RT}=$ raiz tuberosa; $\mathrm{R} / \mathrm{P}=$ razão raiz/parte aérea.

\begin{tabular}{|c|c|c|c|c|c|c|}
\hline Tratamento & $\mathbf{L F}(\mathbf{g})$ & $\mathrm{C}(\mathrm{g})$ & $\mathbf{R}(\mathbf{g})$ & RF (g) & RT (g) & R/PA (g.g-1) \\
\hline Pleno sol com inóculo & $0,868 \pm 0,482 \mathrm{a}$ & $0,256 \pm 0,156 \mathrm{a}$ & $0,063 \pm 0,038 \mathrm{a}$ & $0,123 \pm 0,090 \mathrm{~b}$ & $1,339 \pm 1,007 \mathrm{a}$ & $3,266 \pm 4,645 \mathrm{a}$ \\
\hline Pleno sol sem inóculo & $0,718 \pm 0,598 \mathrm{a}$ & $0,238 \pm 0,248 \mathrm{a}$ & $0,047 \pm 0,051 \mathrm{a}$ & $0,236 \pm 0,291 \mathrm{ab}$ & $0,689 \pm 0,763 \mathrm{a}$ & $4,158 \pm 6,077 \mathrm{a}$ \\
\hline $70 \%$ Sombra com inóculo & $0,708 \pm 0,293 \mathrm{a}$ & $0,383 \pm 0,241 \mathrm{a}$ & $0,049 \pm 0,028 \mathrm{a}$ & $0,213 \pm 0,099 \mathrm{ab}$ & $0,985 \pm 0,504 \mathrm{a}$ & $1,204 \pm 0,583 \mathrm{a}$ \\
\hline $70 \%$ Sombra sem inóculo & $0,699 \pm 0,243 \mathrm{a}$ & $0,305 \pm 0,168 \mathrm{a}$ & $0,052 \pm 0,023 \mathrm{a}$ & $0,339 \pm 0,156 \mathrm{a}$ & $1,198 \pm 0,511 \mathrm{a}$ & $1,638 \pm 0,856 \mathrm{a}$ \\
\hline
\end{tabular}

Médias \pm desvio padrão seguidas da mesma letra não diferem significativamente entre si pelo teste de Tukey a $5 \%$ de probabilidade.

Área foliar e área foliar específica (AFE)

A área foliar específica foi duas vezes maior no tratamento $70 \%$ sombra com inóculo quando comparado ao pleno sol com inóculo, sendo estatisticamente diferentes (Tabela 4). Isto sugere que a condição de sombra e com inóculo contribuíram fortemente para a expansão foliar, aumentando assim a área fotossintética e favorecendo o crescimento da planta nestas condições. Verificou-se também que as plântulas dos tratamentos a pleno sol apresentaram as menores médias (Tabela 4).

Tabela 4. AF = Área foliar; $\mathrm{AFE}=$ área foliar específica; $\Psi \mathrm{w}=$ Potencial hídrico foliar; $\mathrm{AR}=$ área radicular; $\mathrm{AF} / \mathrm{AR}=$ razão área foliar/área radicular.

\begin{tabular}{lccccc}
\hline Tratamento & $\mathbf{A F}\left(\mathbf{c m}^{2}\right)$ & $\mathbf{A F E}\left(\mathbf{c m}^{2} \cdot \mathbf{g}^{-\mathbf{1}}\right)$ & $\mathbf{\Psi w}(\mathbf{M P a})$ & $\mathbf{A R}\left(\mathbf{c m}^{2}\right)$ & $\mathbf{A F} / \mathbf{A R}\left(\mathbf{c m}^{2} \cdot \mathbf{c m}^{-2}\right)$ \\
\hline Pleno sol com inóculo & $141,09 \pm 74,19$ a & $165,64 \pm 17,28 \mathrm{~b}$ & $-0,55 \pm 0,09$ a & $47,24 \pm 32,64$ a & $13,380 \pm 30,236$ a \\
Pleno sol sem inóculo & $115,51 \pm 107,87 \mathrm{a}$ & $157,37 \pm 73,20 \mathrm{~b}$ & $-0,53 \pm 0,26$ a & $47,52 \pm 51,60 \mathrm{a}$ & $13,734 \pm 22,447 \mathrm{a}$ \\
70 \% Sombra com inóculo & $208,25 \pm 68,37$ a & $340,04 \pm 189,28$ a & $-0,44 \pm 0,19$ a & $71,84 \pm 28,27$ a & $3,324 \pm 1,813$ a \\
70\% Sombra sem inóculo & $210,77 \pm 71,08$ a & $303,60 \pm 17,50 \mathrm{ab}$ & $-0,51 \pm 0,19$ a & $79,14 \pm 23,11 \mathrm{a}$ & $2,818 \pm 1,050 \mathrm{a}$ \\
\hline
\end{tabular}

Médias \pm desvio padrão seguidas da mesma letra não diferem significativamente entre si pelo teste de Tukey a $5 \%$ de probabilidade.

Área radicular e razão da área foliar/área radicular

O efeito do sombreamento tendeu a diferir entre os tratamentos de luz, sendo a área radicular maior no tratamento a $70 \%$ de sombreamento, enquanto que a relação da área foliar/área radicular foi superior nos tratamentos sob pleno sol (Tabela 4).

\section{Potencial hídrico foliar}

As plântulas não apresentaram diferenças significativas de potencial hídrico entre os tratamentos, tanto nas condições de luz, quanto na presença ou ausência de rizobactérias (Tabela 4).

\section{Discussão}

$\mathrm{O}$ ambiente sombreado foi o fator que mais influenciou no crescimento das plântulas. De acordo com Moraes Neto et al., (2000), algumas plantas são capazes de crescerem rapidamente em condições de sombreamento, isso é uma estratégia para fugir das condições de baixa luminosidade, ou seja, um mecanismo de plasticidade da espécie. Em busca de luz, a planta investe no alongamento celular, em decorrência disso, ocorrerá aumento aéreo da planta (King, 1994).

Estes resultados corroboram dados de Andrade (2012), que investigou cinco espécies da Caatinga, dentre elas, M. urundeuva, constatando que as plantas apresentaram maior diâmetro caulinar e maior crescimento da parte aérea, em casa de vegetação, em relação àquelas do 
tratamento sob pleno sol. Resultados semelhantes também foram encontrados por Girão (2013), que avaliou o crescimento inicial de quatro quimiotipos de aroeira a pleno sol e em casa de vegetação, sendo que, em casa de vegetação, as plântulas apresentaram maior crescimento. Ao contrário, Ramos et al. (2004), analisando o desenvolvimento inicial de Amburana cearensis (Allemão) A.C. Smith, em diferentes condições de sombreamento, aos 14 meses, encontrou maiores médias para o diâmetro do coleto e altura das plantas a pleno sol, indicando caráter heliófilo da espécie. Certamente, as respostas das plantas de diferentes espécies devem ter influência também da situação ecológica de tal espécie no ambiente, se seria pioneira ou tardia (Ricklefs, 2010). Porém, sob condições mais estressantes, as bactérias também podem ajudar no crescimento, como foi visto no tratamento a pleno sol, no qual a inoculação da bactéria Azospirillum lipoferum ajudou no desenvolvimento e incremento no diâmetro do coleto das plântulas. Segundo Didonet (1993), existem fitormônios que são produzidos a partir da inoculação de A. lipoferum na planta, os quais promovem o crescimento da planta. Martínez-Morales et al. (2003) relatam que o gênero Azospirillum, em testes com plântulas de milho, mostrou que a biossíntese de fitormônios, assim como as auxinas, ajudaram no crescimento das plântulas.

Segundo Kitao et al. (2000), plantas sob altas irradiâncias podem mostrar sinais de sofrimento, pois tenderão a absorver mais fótons de luz do que sua capacidade de utilização, como consequência irá ocorrer uma fotoinibição, podendo chegar até a morte de plantas. Com isso, sugere-se que as bactérias auxiliaram as plântulas de $M$. urundeuva a reduzir o estresse causado pela absorção de fótons, uma vez que a mortalidade de plântulas foi reduzida no tratamento sob pleno sol com inóculo. Desta forma, estudos que avaliem esta relação em nível bioquímico seriam pertinentes.

Quanto à emissão de folhas, segundo Nodari et al. (1999), devido à senescência e ao surgimento de novas folhas, o número de folhas não é um caráter muito adequado para apresentar alterações no desenvolvimento de plantas sob condições de luminosidade ou sombreamento. No entanto, somada com outros caracteres avaliados neste estudo, como a altura e o diâmetro do coleto, as plântulas de $M$. urundeuva se desenvolveram melhor sob condições de sombreamento.

Em condições de seca, o estresse ativa o hormônio vegetal etileno, o qual regula a homeostase da planta (Glick et al., 2007), o qual, de acordo com Brown (1997), o gás etileno causa a perda de órgão vegetativo, como ocorre através da abscisão foliar. Porém, segundo Glick et al. (2007), o 1-aminociclopropano-1-carboxilato (ACC) desaminase produzida pela bactéria é capaz de degradar o precursor de etileno ACC e possibilita a diminuição do estresse e traz de volta o crescimento normal das plantas. Com isso, consequentemente, também há redução da queda de folhas, como foi verificado neste caso.

O DPV e a disponibilidade de água no solo influenciam no aumento de temperatura foliar. Consequentemente, causam redução na abertura estomática e diminuição da transpiração e aumento da Tf (Felsemburg, 2009; Mansur \& Barbosa, 2000). Estes resultados sugerem que deve ter havido uma maior evaporação de água do solo nos tratamentos onde as plantas estavam sob pleno sol; consequentemente, ocorreu estresse nas mesmas, aumentando a sua Tf. O DPV também contribuiu para o aumento da Tf, visto que nos horários mais quentes do dia observou-se uma maior tendência de aumento de Tf, indicando que nestes horários a UR estava mais baixa.

Era esperado que a temperatura foliar das plântulas do tratamento pleno sol com inóculo fosse mais baixa. Contudo, não foi o que ocorreu ao observar a variação ao longo dos dias avaliados. A Tf das plântulas daquele tratamento foi superior na maioria dos dias do que os tratamentos sem inóculo. Isso sugere que o aumento da temperatura não prejudicou o mecanismo fotossintético, uma vez que as plântulas apresentaram um bom desenvolvimento em altura e diâmetro.

A maior alocação de biomassa radicular verificada nas plântulas a pleno sol pode ser explicada pelo fato de estarem onde há maior evaporação de água do solo, sugerindo a necessidade de alongamento de raízes para busca de água. Resultado semelhante foi encontrado por Marimon et al. (2007), avaliando o desenvolvimento inicial e partição de biomassa de Brosimum rubescens Taub. (Moraceae) sob diferentes níveis de sombreamento, e verificaram que as plantas que estavam a pleno sol alocaram maior biomassa para as raízes. O maior acúmulo de biomassa radicular pode ser explicado pelo aumento do ácido abscísico (ABA) que promove o surgimento e alongamento de raízes secundárias, além de aumentar o fluxo de água na planta, mantendo a turgescência dos tecidos vegetais (Taiz \& Zeiger, 2002). Segundo Yang et al. (2009), em condições estressantes como a seca, as plantas afetadas e com inoculação de RPCP, podem ser capazes de aumentar os níveis de fitormônios, como o $\mathrm{ABA}$, o qual induzirá a 
planta a produzir mais raízes, favorecendo um melhor desenvolvimento do vegetal. Porém, neste caso não foi verificado diferença estatística quanto a inoculação da RPCP.

As menores médias de área foliar específica observadas nas plântulas a pleno sol indicam que suas folhas se tornaram mais espessas e com menores áreas foliares, que é uma forma de minimizar a incidência luminosa e a perda de água (Pérez-Harguindeguy et al., 2013). Isso sugere que esta espécie se ajusta a tais condições ambientais, indicando que há uma plasticidade quanto a luminosidade. Segundo Nakazono et al. (2001), plantas submetidas a uma alta luminosidade tendem a ter folhas com espessura maior, sendo um benefício para a mesma estar exposta a uma alta irradiação, quando diminuem a área foliar para evitar a perda de água por transpiração. Por outro lado, de acordo com Lima et al. (2006), plantas submetidas a uma baixa luminosidade tendem a aumentar a área foliar para ter uma maior área de absorção de fótons. A AFE é uma boa medida do ajuste das plantas às condições ambientais, uma vez que, com o aumento da área foliar, houve uma redução da biomassa foliar por unidade de área, e viceversa. Resultados semelhantes também foram registrados por Engel \& Pogiani (1990), que investigaram variações na área foliar nas espécies A. cearensis, Zeyheria tuberculosa (Vell) Bureau e Tabebuia avellanedae Lorentz ex Grisebach, sob a influência do sombreamento no crescimento de plântulas.

A área radicular do tratamento mais sombreado foi quase $70 \%$ maior que o tratamento a pleno sol. Por outro lado, a razão área foliar e área radicular foi pelo menos quatro vezes maior nos tratamentos a pleno sol quando comparado aos tratamentos mais sombreados. Isto indica que em condições de disponibilidade de água as plântulas de $M$. urundeuva investem em maior receptação de luz, ou seja, maior área foliar em detrimento de raízes finas.

Quando analisado o potencial hídrico, não foi encontrada nenhuma variação entre os tratamentos. Certamente, o potencial hídrico é uma variável cujos valores se ajustam em função da demanda hídrica da planta e das condições de déficit de pressão e vapor (Taiz \& Zeiger, 2004). Isso é ratificado quando se observa que a área foliar específica se ajustou à condição de luz, sendo maior na condição de sombra (Tabela 4), na qual as perdas de águas são mais reduzidas. Além disso, verificou-se, também, que a área de raízes finas foi maior no tratamento sombreado. Resultados encontrados por Trovão et al. (2004), avaliando o potencial hídrico de espécies da
Caatinga sob diferentes níveis de umidade no solo, mostraram resultados semelhantes para $M$. urundeuva, com adaptações morfo-fisiológicas adquiridas devido às condições climáticas do domínio Caatinga e do tipo de solo na região semiárida.

\section{Conclusão}

$\mathrm{O}$ sombreamento favoreceu $\mathrm{o}$ desenvolvimento das plântulas de Myracrodruon urundeuva Allemão, independente da inoculação das RPCP (Azospirillum lipoferum), entretanto, sob pleno sol, as RPCP se mostraram bastante eficazes no desenvolvimento das plântulas, minimizando o estresse. Desta forma, fica evidente que a aplicação de sombreamento e a inoculação de RPCP são alternativas relevantes a serem consideradas em planos de reflorestamento de áreas degradadas, tendo em vista o melhor desempenho das plântulas nestas condições.

\section{Agradecimentos}

Ao Programa Institucional de Bolsas de Iniciação Científica-PIBIC/Conselho Nacional de Desenvolvimento Científico e Tecnológico$\mathrm{CNPq} /$ Universidade Federal Rural de Pernambuco-UFRPE e à Fundação de Amparo à Ciência e Tecnologia de Pernambuco-FACEPE pelo apoio financeiro (Processo $\mathrm{n}^{\circ}$ APQ-04012.03/14).

\section{Referências}

AUGSPURGER, C. K. 1984. Light requirements of neotropical tree seedlings: a comparative study of growth and survival. Journal of Ecology, v. 77, p. 777-795.

ANDRADE, M. W.; LUZ, J. M. Q.; LACERDA, S. A.; MELO, P. R. A. 2000. Micropropagação da Aroeira (Myracrodruon urundeuva Fr. All) Ciência e Agrotecnologia, v. 24, n. 1, p. 174-180.

ANDRADE, I. L. 2012. Morfologia de sementes, plântulas e crescimento inicial de cinco espécies da caatinga. Dissertação de Mestrado, Universidade Federal do Ceará, Fortaleza., Ceará, Brasil. 70p.

ANDRADE LIMA, D. 1989. Plantas das Caatingas. Rio de Janeiro: Academia Brasileira de Ciências.

BARBOSA, M. L.; SILVA, T. G. F.; SILVA, A. C.; ALMEIDA, M. G.; LIMA, A. L. A.; SOUZA, C. A. A. 2013. Crescimento Inicial de Espécies Ocorrentes no Semiárido Brasileiro: Biomassa, Biometria e Análise Morfogênica. Revista 
Brasileira de Geografia Física, v. 6, n. 3, p. 522539.

BROWN, K. M. 1997. Ethylene and abscission. Physiologia Plantarum, v. 100, n. 3, p. 567-576.

CORNELISSEN, J. H. C.; LAVOREL, S.; GARNIER, E.; DÍAZ, S.; BUCHMANN, N.; GURVICH, D. E.; REICH, P. B.; TER STEEG, H.; MORGAN, H. D.; VAN DER HEIJDEN, M. G. A.; PAUSAS, J. G.; POOTER, H. 2003. A handbook of protocols for standarised and easy measurement of plant functional traits worldwide. Australian Journal of Botany, v. 51, n. 4. p. 335380.

DIDONET, A. D. 1993. Aspectos do mecanismo de ação fisiológica associada à promoção do crescimento radicular de trigo (Triticum aestivum L.) por bactérias do gênero Azospirillum. Tese de Doutorado, Instituto de Biologia, Universidade Estadual de Campinas, Campinas, São Paulo. Brasil. 80p.

ENGEL, V. L.; POGGIANI, F. 1990. Influência do sombreamento sobre o crescimento de mudas de algumas essências nativas e suas implicações ecológicas e silviculturais. IPEF, v. 43, n. 44, p.110.

FALLIK, E.; OKON, Y. 1996. Inoculation of Azospirillum brasilense: biomass production, survival and growth promotion of Setaria italica and Zea mays. Soil Biology and Biochemistry, v. 28, n. 1, p. 123-126.

FELSEMBURG, C. A. 2009. Respostas fotossintéticas à variação da temperatura foliar do dossel na Flona dos Tapajós-PA. Tese de Doutorado, Universidade de São Paulo, Piracicaba, São Paulo, Brasil.

FETENE, M.; FELEKE, Y. 2001. Growth and photosynthesis of seedlings of four tree species from a dry Tropical afromontane forest. Journal of Tropical Ecology, v.17, p. 269-283.

GENTRY, A. H. 1995. Diversity and floristic composition of neotropical dry forests. In: BULLOCK, S. H.; MOONEY, H. A.; MEDINA, E. (eds.). Seasonally dry tropical forests Cambridge University Press, New York, pp. 146194.

GIRÃO, K. T. 2013. Biometria de sementes, morfologia de plântulas e crescimento inicial de mudas de quimiotipos de Myracrodruon urundeuva Allemão. Dissertação de Mestrado,
Universidade Federal do Ceará, Fortaleza, Ceará, Brasil.

GLICK, B. R.; TODOROVIC, B.; CZARNY, J.; CHENG, Z.; DUAN, J.; MCCONKEY, B. 2007. Promotion of plant growth by bacterial ACC deaminase. Critical Reviews in Plant Sciences, v. 26, p. 227-242.

IBAMA. Lista Oficial das Espécies da Flora Brasileira Ameaçadas de Extinção. 2008. Disponível em: http://www.mma.gov.br/estruturas/ascom_boletin s/_arquivos/83_19092008034949.pdf. Acesso em: 04 de fevereiro de 2017.

KITAO, M.; LEI, T. T.; KOIKE, T.; TOBITA, H.; MARUYAMA, Y. 2000. Susceptibility to photoinhibition of three deciduous broadleaf tree species with different successional traits raised under various light regimes. Plant, Cell and Environment, v. 23, p. 81-89.

KUSS, A. V.; KUSS, V. V.; HOLTZ, E. K.; LOVATO, T. 2007. Inoculação de bactérias diazotróficas e Desenvolvimento de plântulas de arroz irrigado em Solução nutritiva e câmara de crescimento. Revista da FZVA. Uruguaiana, v. 14, n. 2, p. 23-33.

KING, D. 1994. Influence of light level on the growth and morphology of saplings in a Panamanian forest. American Journal of Botany, v. 81, n. 8 , p. $948-957$.

KOZLOWSKI T. T.; KRAMER P.J.; PALTARDY S.G. 1991. The physiological ecology of woody plants. San Diego: Academic Press.

LEAL I. R.; TABARELLI. M.; SILVA. J. M. C. 2003. Ecologia e Conservação da Caatinga. Recife: Ed. Universitária da UFPE. 822p.

LIMA, J. D.; SILVA, B. M. S.; MORAES, W. S. 2006. Efeito da luz no crescimento de plântulas de Virola surinamensis (Rol.) Warb. Revista Científica Eletrônica de Engenharia Florestal. v. 4, n. 8, 10p.

MANSUR, R. J. C. N.; BARBOSA, D. C. A. 2000. Comportamento fisiológico em plantas jovens de quatro espécies lenhosas da caatinga submetidas a dois ciclos de estresse hídrico. Phyton, v. 68, p. 97-106. 
MARTÍNEZ-MORALES, L. J.; SOTO-URZÚA, L.; BACA, B. E.; SÁNCHEZ-AHÉDO, J. A. 2003. Indole-3-butyric acid (IBA) production in culture medium by wild strain Azospirillum brasilense. FEMS Microbiology Letters, v. 228, p. 167-173.

MARIMON, B. S.; FELFILI, J. M.; JUNIOR, B. H. M.; FRANCO, A. C.; FAGG, C. W. 2008. Desenvolvimento inicial e partição de biomassa de Brosimum rubescens Taub. (Moraceae) sob diferentes níveis de sombreamento. Acta Botanica Brasilica, v. 22, n. 4, p. 941-953.

MILES L.; NEWTON, A.; DEFRIES, R., RAVILIOUS, C.; MAY, I.; BLYTH, S.; KAPOS, V.; GORDON, J. 2006. A global overview of the conservation status of tropical dry forests. Journal of Biogeography, v. 33, p. 491-505.

MOREIRA, F. M. S.; SIQUEIRA, J. O. 2006. Fixação biologica de nitrogênio atmosférico. In: MOREIRA, F. M. S.; SIQUEIRA, J. O. Microbiologia e Bioquímica do Solo. $2^{\text {a }}$ ed., Lavras: Editora UFLA, pp. 449-542.

MORAES NETO, S. P.; GONÇALVES, J. L. M.; TAKAKI, M.; CENCI, S.; GONÇALVES, J. C. 2000. Crescimento de mudas de algumas espécies arbóreas que ocorrem na mata atlântica, em função do nível de luminosidade. Revista Árvore, v. 24, n. 1 , p. 35-45.

NAKAZONO, E. M.; COSTA, M. C.; FUTATSUGI, K.; PAULILO, M. T. S. 2001. Crescimento inicial de Euterpe edulis Mart. em diferentes regimes de luz. Revista brasileira de Botânica, v. 24, n. 2, p. 173-179.

NODARI, R. O.; REIS, M. S.; FANTINI, A. C.; MANTOVANI, A.; RUSCHEL, A.; WEITER, L. J. 1999. Crescimento de mudas de palmiteiro (Euterpe edulis Mart.) em diferente condições de sombreamento e densidade. Revista Árvore, v. 23, n. 3, p. 285-292.

NUNES, Y. R. F.; FAGUNDES, M.; ALMEIDA, H. S.; VELOSO, M. D. M. 2008. Aspectos Ecológicos da Aroeira (Myracrodruon urundeuva Allemão-Anacardiaceae): Fenologia e germinação de sementes. Revista Árvore, v. 32, n. 2, p. 233243.

PÉREZ-HARGUINDEGUY, N.; DÍAZ, S.; GARNIER, E.; LAVOREL, S.; POORTER, H.; JAUREGUIBERRY, P.; BRET-HARTE, M. S.; CORNWELL, W. K.; CRAINE, J. M.;
GURVICH, D. E.; URCELAY, C.; VENEKLAAS, E. J.; REICH, P. B.; POORTER, L.; WRIGHT, I. J.; RAY, P.; ENRICO, L.; PAUSAS, J. G.; VOS, A. C.; BUCHMANN, N.; FUNES, G.; QUÉTIER, F.; HODGSON, J. G.; THOMPSON, K.; MORGAN, H. D.; TER STEEGE, H.; VAN DER HEIJDEN, M.G. A.; SACK, L.; BLONDER, B.; POSCHLOD, P.; VAIERETTI, M. V.; CONTI, G.; STAVER, A. C.; AQUINO, S.; CORNELISSEN, J. H. C. 2013. New handbook for standardised measurement of plant functional traits worldwide. Australian Journal of Botany, v. 61, n. 3, p. 167-234.

RAMOS, K. M. O.; FELFILI, J. M.; FAGG, C. W.; SOUSA-SILVA, J. C.; FRANCO, A. C. 2004. Desenvolvimento inicial e repartição de biomassa de Amburana cearensis (Allemão) A.C. Smith, em diferentes condições de sombreamento. Acta Botanica Brasilica, v. 18, n. 2, p. 351-358.

RICKLEFS, R. E. 2010. Economia da natureza: Sucessão ecológica e desenvolvimento da comunidade. Guanabara koogan. Rio de Janeiro. $6^{\mathrm{a}}$ ed. pp. 349-365.

RIZZINI, C. T. 1995. Árvores e Madeiras Úteis do Brasil: manual de dendrologia brasileira. $2^{\mathrm{a}} \mathrm{ed}$. São Paulo, Edgard Blucher. 296p.

SAMPAIO, E. V. S. B.; RODAL, M. J. N. 2000. Fitofisionomia da Caatinga. In: Avaliação e identificação de ações prioritárias para a conservação, utilização sustentável e repartição de benefícios da biodiversidade do bioma Caatinga. Petrolina, PE. Documento para discussão no GP Botânica. pp. 2-14.

SACRAMENTO, A. C. et al. 2013. Parque Estadual Mata da Pimenteira: Plano de Manejo. ed.1. Serra Talhada-PE.

SILVA, T. G. F.; ALMEIDA, A. Q. 2013. Climatologia e Características Geomorfológicas. In: SANTOS, E. M.; JÚNIOR, M. M.; SILVACAVALCANTI, J. S.; ALMEIDA, G. V. L. (org) Parque Estadual Mata da Pimenteira: Riqueza Natural e Conservação da Caatinga. Recife: EDUFRPE, 257p.

SILVEIRA, E. L. 2008. Inoculações de bactérias promotoras de crescimento no cultivo de arroz em solução nutritiva. Jaboticabal. Tese de Doutorado, Universidade Estadual Paulista. Jaboticabal, São Paulo, Brasil. 
TAIZ, L.; ZEIGER, E. 2002. Plant Physiology. 3 ed. Sinauer Associates, Inc., Publishers.

TAIZ, L.; ZEIGER, E. 2004. Fisiologia Vegetal. 3 ed. Porto Alegre: Artmed, 719p.

TROVÃO, D. M. B. M.; FERNANDES, P. D.; ANDRADE, L. A.; NETO, J. D.; OLIVEIRA, A. B.; QUEIROZ, J. A. 2004.. Avaliação do potencial hídrico de espécies da Caatinga sob diferentes níveis de umidade no solo. Revista de Biologia e Ciências da Terra. v. 4, n. 2.

YANG, J.; KLOEPPER, J. W.; RYU, C. M. 2009. Rhizosphere bacteria help plants tolerate abiotic stress. Trends in Plant Science, v. 14, n. 1, p. 1-4. 